\title{
PETROLOGY OF BADENIAN IGNIMBRITES, GUTÂI MTS. (EASTERN CARPATHIANS)
}

\author{
ALEXANDRINA FÜLÖP \& MARINEL KOVACS ${ }^{1}$
}

\begin{abstract}
Gutâi Mts., part of inner Carpathians volcanic arc, consist of products of felsic and intermediate volcanism. The previously known "Badenian Rhyodacitic Formation", expression of the felsic explosive volcanism, is composed of a well-defined basal unit of ignimbrites, overlain by a sequence of resedimented volcaniclastics of similar origin, interlayered with mudstones.

The petrography of ignimbrites shows matrix-supported lapilli tuffs having a heterogeneous composition with insignificant lateral variations. The juvenile components, pumice, glass shards and crystals of plagioclase, quartz and biotite are predominant; cognate nonvesicular glassy clasts are rare, unlike accidental clasts of sedimentary and metamorphic rocks which are abundant. Pyroxene andesite accidental lithic clasts and pyroxene crystal clasts are scarce.

The geochemical study of ignimbrites pointed out their rhyolitic character and geochemical signatures resembling subduction-related volcanics. Petrogenesis of ignimbrites involves complex evolution in the crustal magma chamber of some enriched (by subduction components) mantle melts. Magmagenesis could be related to the uprise of the astenospheric mantle during the back-arc opening of the Intracarpathian region.
\end{abstract}

Keywords: Gutâi Mts., ignimbrites, fiamme, rhyolitic, calc-alkaline magmas.

\section{INTRODUCTION}

Gutâi Mts. are components of the inner Carpathians Neogene-Quaternary volcanic chain, built up by complex subduction processes involving the European Plate and two microplates (Alcapa and Tisza-Dacia/Tisia) from the Intracarpathian region (Csontos, 1995; Seghedi et al., 1998). Two major types of calc-alkaline volcanism joined in building up the edifice of Gutâi Mts.: a felsic explosive, extensional-type, less extended and mostly buried and an intermediate mostly effusive, arc-type, widespread and outcropping.

The ignimbrites erupted $15.4 \pm 0.6 \mathrm{Ma}$ ago (Fülöp, 2001) and spread over the Paleogene flysch, on the southern part of Gutâi Mts. The outcrops occur from Seini to Firiza lake showing the same welded deposit (Fig. 1). Their genesis is related to magmatic explosions followed by caldera collapse, developed in the southwestern corner of the mountains (Fülöp, 2001). Combined volcanic and sedimentary processes resulted in the intracaldera emplacement of a thick sequence of volcaniclastic rocks composed of resedimented volcaniclastics of ignimbritic origin, interlayered with basinal mudstones (Fülöp, 2002).

\footnotetext{
${ }^{1}$ North University Baia Mare, Faculty of Mineral Resources and Environment, 62/A, Victor Babeş street, Baia Mare 4800
} 
First descriptions belong to Rădulescu (1958). The whole succession of ignimbrites and resedimented volcaniclastics has previously been described as a volcano-sedimentary formation by Borcoş et al. (1972). They separated volcanogenic and terrigeneous deposits, based on petrographic approach. Later on, Kovacs et al. (1989), Fülöp et al. (1991) described the physical components of the formation on a petrographical basis, attempting to point out elements having genetic significance. Fülöp (2001) outlined the major genetic types of the deposits, attempting to reconstruct volcanic and sedimentary processes and the way they had interacted in building up the "Badenian Rhyodacitic Formation". The ignimbrites played the major role because their genesis, style of eruption and parental magma had set the ongoing volcanic and sedimentary evolution.

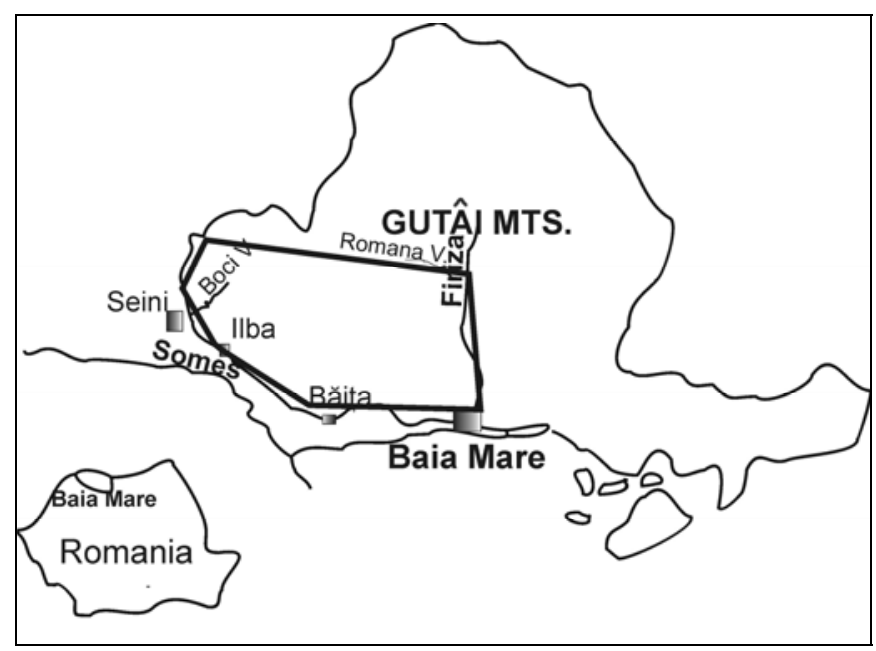

Fig. 1. Areal distribution of ignimbrites on the southern border of Gutâi Mts.

\section{PETROGRAPHY OF IGNIMBRITES}

The ignimbrites are pyroclastic flow deposits containing pumice as major constituent (Druitt, 1998). They are represented by matrix-supported lapilli tuffs with heterogeneous composition. The physical constituents are: juvenile and cognate pyroclasts and accidental lithic clasts. The coarser components are lapillisized juveniles such as pumice and non vesicular cognates and accidental lithic clasts; the finer components are glass shards which form the matrix. The different proportions of these components are reflected by the modal composition (Tab. 1).

Juvenile pyroclasts are recognized as pumice lapilli, crystals and matrix components. Pumice lapilli and glass shards are predominant. Pumice has a distinctive pattern: it is flattened and oriented forming fiamme (Plate II, Fig. 1). The same flattened character may be recognized within the matrix where elongated glass shards enhance the secondary sedimentary structure known as eutaxitic texture (Fülöp, 2000). It is typical for the proximal facies of ignimbrites 
(Seini-llba area, Fülöp, 2001). However, the original morphologies of glass shards are still preserved: cuspate, $\mathrm{X}$ - and $\mathrm{Y}$ - shaped morfologies of glass shards coexist with slightly vesicular micropumice in the distal facies of ignimbrites (Firiza area, Fülöp, 2000, 2001). Matrix components are usually replaced by fine silicaalkaline feldspar aggregates, adularia-quartz and clay minerals or carbonates (Plate II, Fig. 1). Fiamme are more or less replaced by secondary minerals such as aggregates of trydimite/cristobalite and alkaline feldspar, phyllosilicates, quartz, adularia and carbonates. The secondary assemblages obliterate the mostly deformed vesicular microtexture.

Modal composition of ignimbrites

Table 1

\begin{tabular}{|c|l|c|c|c|c|c|c|}
\hline Sample & \multicolumn{1}{|c|}{ Location } & Pumice & Plagioclase & Quartz & Biotite & Matrix & Xenoliths \\
\hline $\mathbf{2 2 1}$ & Boci V. & 11.95 & 13.6 & 2.98 & 0.69 & 70.75 & - \\
\hline $\mathbf{1}$ & Colbu V. & 8.52 & 12.4 & 3.8 & 1.4 & 71.08 & 2.8 \\
\hline $\mathbf{4 0 0}$ & Lupu V. & 6.78 & 17.43 & 5.22 & 2.71 & 62.58 & 6.27 \\
\hline $\mathbf{4 2}$ & Coroana de Aur & 9.27 & 13.5 & 2.82 & 0.72 & 54.77 & 18.92 \\
\hline $\mathbf{3 0 1}$ & Romana V. & 7.23 & 17.27 & 1.1 & 2.2 & 68.4 & 3.8 \\
\hline
\end{tabular}

Most of the crystals are plagioclase (Tab. 1). They form subhedral to anhedral crystals, very rarely fresh, usually pseudomorphosed by adularia, sericite, clay minerals and carbonates (Plate I, Fig. 1; Plate III, Fig. 1). The chemical composition of fresh crystals of plagioclase have been determined by microprobe analysis (JEOL 2000 electron microprobe at Birkbeck College, London, Tab. 2).

Table 2

Plagioclase representative chemical composition

\begin{tabular}{|c|c|c|c|c|c|c|c|c|}
\hline Analysis & plg 1 & plg 2 & plg 3 & plg 4 & plg 5 & plg 6 & plg 7 & plg 8 \\
\hline $\mathrm{SiO}_{2}$ & 58.08 & 57.93 & 60.2 & 60.18 & 58.53 & 61.09 & 60.3 & 62.14 \\
\hline $\mathrm{Al}_{2} \mathrm{O}_{3}$ & 28.18 & 27.4 & 26.22 & 25.9 & 26.94 & 25.06 & 25.77 & 24.66 \\
\hline $\mathrm{MgO}$ & & 0 & 0 & 0 & 0 & 0 & 0 & 0 \\
\hline $\mathrm{CaO}$ & 8.17 & 8.55 & 7.24 & 6.66 & 8.09 & 6.01 & 6.92 & 5.33 \\
\hline $\mathrm{MnO}$ & 0 & 0 & 0 & 0 & 0 & 0 & 0 & 0 \\
\hline $\mathrm{FeO}$ & 0.26 & 0 & 0 & 0.28 & 0.14 & 0.2 & 0.11 & 0.17 \\
\hline $\mathrm{BaO}$ & & 0 & 0 & 0 & 0 & 0 & 0 & 0 \\
\hline $\mathrm{Na}_{2} \mathrm{O}$ & 5.23 & 5.43 & 5.9 & 6.15 & 5.54 & 6.41 & 6.12 & 7.3 \\
\hline $\mathrm{K} \mathrm{O}_{2}$ & 0.09 & 0.43 & 0.52 & 0.56 & 0.39 & 0.62 & 0.52 & 0.4 \\
\hline $\mathrm{Total}$ & 100.01 & 99.74 & 100.08 & 99.73 & 99.63 & 99.39 & 99.74 & 100 \\
\hline Based on 8 & $0 x y g e n s$ & & & & & & & \\
\hline $\mathrm{Si}$ & 2.580 & 2.589 & 2.667 & 2.677 & 2.614 & 2.719 & 2.681 & 2.745 \\
\hline $\mathrm{Al}$ & 1.475 & 1.443 & 1.369 & 1.357 & 1.418 & 1.314 & 1.350 & 1.284 \\
\hline $\mathrm{Mg}$ & 0 & 0 & 0 & 0 & 0 & 0 & 0 & 0 \\
\hline $\mathrm{Ca}$ & 0.388 & 0.409 & 0.343 & 0.317 & 0.387 & 0.286 & 0.329 & 0.252 \\
\hline
\end{tabular}




\begin{tabular}{|c|c|c|c|c|c|c|c|c|}
\hline $\mathrm{Mn}$ & 0 & 0 & 0 & 0 & 0 & 0 & 0 & 0 \\
\hline $\mathrm{Fe}$ & 0.0096 & 0 & 0 & 0.010 & 0.005 & 0.0074 & 0.0040 & 0.0062 \\
\hline $\mathrm{Ba}$ & 0 & 0 & 0 & 0 & 0 & 0 & 0 & 0 \\
\hline $\mathrm{Na}$ & 0.450 & 0.470 & 0.506 & 0.530 & 0.479 & 0.553 & 0.527 & 0.625 \\
\hline $\mathrm{K}$ & 0.0051 & 0.0245 & 0.0293 & 0.0317 & 0.0222 & 0.0352 & 0.0294 & 0.0225 \\
\hline Total & 4.909 & 4.936 & 4.916 & 4.925 & 4.927 & 4.917 & 4.922 & 4.936 \\
\hline Ab (Na/Ca) & 53.344 & 52.022 & 57.599 & 60.300 & 53.957 & 63.220 & 59.496 & 69.466 \\
\hline $\mathrm{An}(\mathrm{Na} / \mathrm{Ca})$ & 46.051 & 45.267 & 39.060 & 36.086 & 43.543 & 32.756 & 37.176 & 28.028 \\
\hline $\mathrm{Or}$ & 0.604 & 2.710 & 3.340 & 3.612 & 2.499 & 4.023 & 3.326 & 2.504 \\
\hline $\mathrm{Ce}$ & 0 & 0 & 0 & 0 & 0 & 0 & 0 & 0 \\
\hline
\end{tabular}

Similar chemical analyses have been carried out on fresh crystals of biotite (Tab. 3).

Table 3

Biotite representative chemical compositions

\begin{tabular}{|c|c|c|c|c|c|}
\hline Analysis & bi1 & bi2 & bi3 & bi4 & bi5 \\
\hline $\mathrm{SiO}_{2}$ & 35.73 & 35.45 & 35.64 & 35.19 & 34.81 \\
\hline $\mathrm{TiO}_{2}$ & 4.81 & 4.75 & 4.87 & 4.27 & 4.66 \\
\hline $\mathrm{Al}_{2} \mathrm{O}_{3}$ & 14.29 & 14.16 & 14.4 & 14.09 & 13.85 \\
\hline $\mathrm{Cr}_{2} \mathrm{O}_{3}$ & 0 & 0 & 0 & 0 & 0 \\
\hline $\mathrm{Fe}_{2} \mathrm{O}_{3}$ & 0 & 0 & 0 & 0 & 0 \\
\hline $\mathrm{MgO}$ & 9.09 & 9.22 & 9.51 & 8.9 & 8.88 \\
\hline $\mathrm{CaO}$ & 0 & 0.06 & 0.06 & 0.13 & 0.09 \\
\hline MnO & 0.09 & 0.24 & 0.15 & 0.11 & 0.14 \\
\hline $\mathrm{FeO}$ & 24.34 & 23.98 & 23.74 & 24.15 & 23.34 \\
\hline $\mathrm{BaO}$ & 0 & 0.63 & 0.41 & 0.62 & 0.63 \\
\hline $\mathrm{Na}_{2} \mathrm{O}$ & 1.09 & 1.41 & 1.55 & 1.01 & 0.96 \\
\hline $\mathrm{K}_{2} \mathrm{O}$ & 8.83 & 8.64 & 8.41 & 8.42 & 8.39 \\
\hline $\mathrm{H}_{2} \mathrm{O}$ & 3.94243 & 3.932614 & 3.961045 & 3.870795 & 3.833017 \\
\hline Total & 102.2124 & 102.4726 & 102.701 & 100.7608 & 99.58302 \\
\hline \multicolumn{6}{|c|}{ based on 22 oxygen atoms } \\
\hline Si & 5.333382 & 5.320158 & 5.302699 & 5.368005 & 5.354257 \\
\hline $\mathrm{Ti}$ & 0.540063 & 0.536206 & 0.545027 & 0.489949 & 0.539151 \\
\hline Al & 2.513956 & 2.504536 & 2.525094 & 2.533147 & 2.510734 \\
\hline $\mathrm{Cr}$ & 0 & 0 & 0 & 0 & 0 \\
\hline $\mathrm{Fe}^{3+}$ & 0 & 0 & 0 & 0 & 0 \\
\hline $\mathrm{Mg}$ & 2.022749 & 2.062755 & 2.109349 & 2.023915 & 2.036182 \\
\hline $\mathrm{Ca}$ & 0 & 0.009648 & 0.009565 & 0.021248 & 0.014832 \\
\hline$M n$ & 0.011379 & 0.030507 & 0.018903 & 0.014213 & 0.018239 \\
\hline
\end{tabular}


PETROLOGY OF BADENIAN IGNIMBRITES, GUTAI MTS. (EASTERN CARPATHIANS)

\begin{tabular}{|c|c|c|c|c|c|}
\hline $\mathrm{Fe}^{2+}$ & 2.216059 & 2.312329 & 2.194769 & 2.403887 & 2.259767 \\
\hline $\mathbf{B a}$ & 0 & 0.03705 & 0.023905 & 0.037062 & 0.037973 \\
\hline $\mathbf{N a}$ & 0.315462 & 0.410278 & 0.447138 & 0.298721 & 0.286297 \\
\hline $\mathbf{K}$ & 1.681469 & 1.654172 & 1.596298 & 1.638567 & 1.646325 \\
\hline Total & 14.63452 & 14.87764 & 14.77275 & 14.82871 & 14.70376 \\
\hline $\mathbf{X ~ F e}$ & 0.522802 & 0.528522 & 0.509923 & 0.542908 & 0.526023 \\
\hline $\mathbf{X ~ M g}$ & 0.477198 & 0.471478 & 0.490077 & 0.457092 & 0.473977 \\
\hline
\end{tabular}

Plotted in Ab-An-Or diagram, plagioclase show almost exclusive andesine compositions, the An content reaching $50 \%$ (Fig. 2)

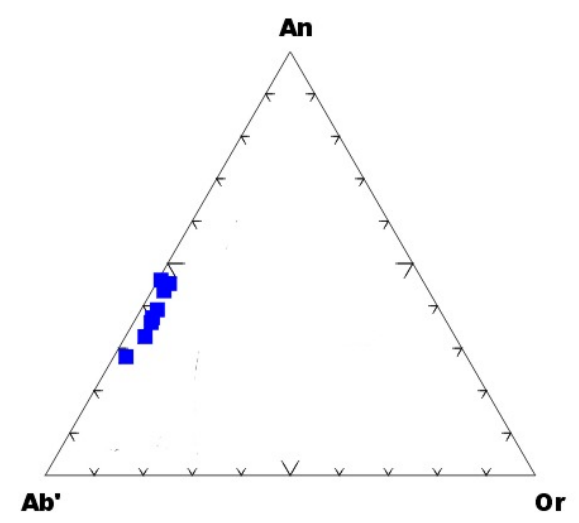

Fig. 2. Plagioclase compositions in Ab-An-Or diagram.

Biotite show homogeneous crystals represented by the intermediate terms of phlogopite-annite series, with high Fe/Mg ratios (Fig. 3). Most of the crystals form slightly undulated lamellae, replaced by hidromuscovite, chlorites, iron oxides and carbonates (Plate I, Fig. 1, 2).

Quartz crystals have irregular shapes, mostly subangular (Plate I, Fig. 1, 2; Plate II, Fig. 1; Plate I, Fig. 1, 2).

The pyroclasts with aphyric or porphyritic texture, composed of non vesicular glass and crystals of plagioclase, quartz and biotite eventually, are interpreted as cognate pyroclasts. They have subangular shapes and some of them show perlitic cracks (Plate II, Fig. 2) or pseudomorphosis by quartz, adularia and carbonates.

Accidental lithic clasts are represented by sedimentary, metamorphic and subordinately igneous rocks. Most of them are elongated and rounded, especially the sedimentary clasts (sandstones, siltstones and mudstones) which are predominant (Plate III, Fig. 1). They represent fluvial debris eroded from the Paleogene flysch and picked up by the ignimbrite-forming ash-flow. Accidental metamorphic clasts (quartzites, crystalline schists) are less frequent (Plate I, Fig. 1). They seem to be broken from the metamorphic basement or reworked as fluvial 
debris. Pyroxene andesites form irregularly shaped clasts, present in the upper half of the ignimbrite sequence (Plate III, Fig. 2).

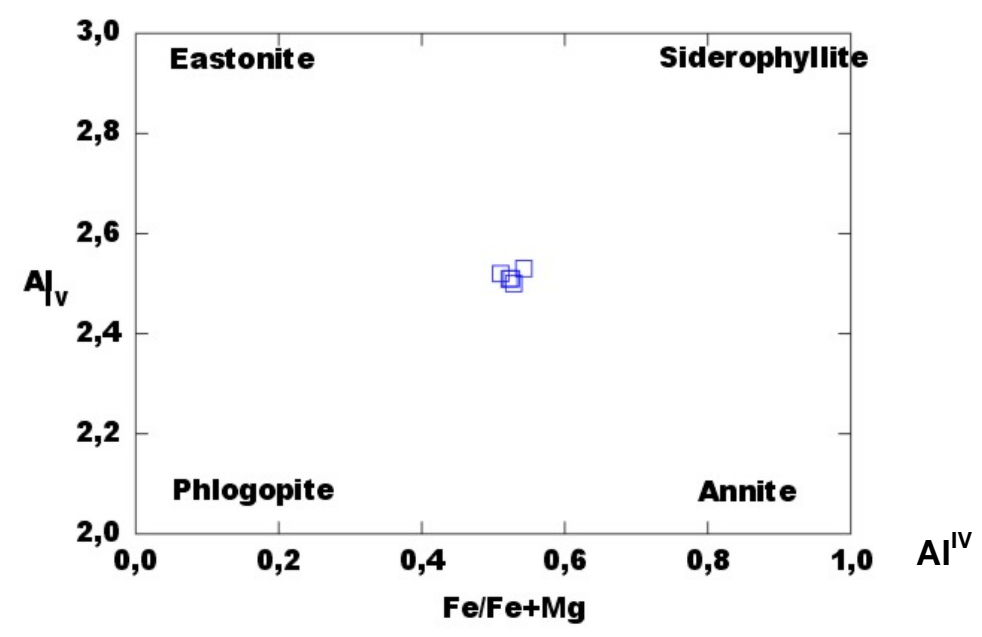

Fig. 3. Biotite composition in $\mathrm{Al}^{\mathrm{IV}}-\mathrm{Fe} / \mathrm{Fe}+\mathrm{Mg}$ diagram.

Pyroxene crystals occur rarely, almost completely replaced by secondary minerals: chlorites, carbonates, iron oxides and hydroxides, pyrite. Typical euhedral and subhedral morphologies have been emphasized.

The andesitic clasts and pyroxene crystals are interpreted as magmatic inclusions from a more basic magma, suggesting magma mingling/mixing processes, possibly related to a zoned magma chamber.

\section{GEOCHEMISTRY}

The geochemical study of the ignimbrites has been achieved on the basis of major, trace and rare earth element geochemistry belonging to two occurences: Bocilor Valley (Seini) and Romană Valley (Firiza) outcrops. The two samples (221 and 301 respectively) are lapilli tuffs composed almost exclusively of juvenile clasts (crystals, fiamme and glass shards) in ratios typical for the whole ignimbrite sequence. Very few accidental lithic clasts are present and they have been excluded from the analyses. Unfortunately, there are no other available outcrops with fresh and homogeneous ignimbrites. The chemical analyses have been carried out at Henry Poincaré University, Nancy, France by ICP-AES (major elements) and by ICP-MS (trace and rare earth elements).

Major element geochemistry (Tab. 4) has demonstrated the rhyolitic composition of the ignimbrites. The two analyses (recalculated on volatile-free basis) plot in the rhyolite field of the TAS diagram (Le Bas et al., 1986-Fig. 4a). The calc-alkaline character of the parental magmas is shown in the AFM diagram (Fig. 4 b). 
Major element analyses of ignimbrites

\begin{tabular}{|c|c|c|c|c|c|c|c|}
\hline Sample & \multicolumn{2}{|c|}{ Location } & $\mathrm{SiO}_{2}$ & $\mathrm{Al}_{2} \mathrm{O}_{3}$ & $\mathrm{Fe}_{2} \mathrm{O}_{3}$ & $\mathrm{MnO}$ & $\mathrm{MgO}$ \\
\hline 221 & \multicolumn{2}{|c|}{ Boci V. } & 68.64 & 15.45 & 2.33 & 0.02 & 0.82 \\
\hline 301 & \multicolumn{2}{|c|}{ Romana V. } & 69.18 & 14.74 & 2.99 & 0.05 & 0.39 \\
\hline Sample & $\mathrm{CaO}$ & $\mathrm{Na}_{2} \mathrm{O}$ & $\mathrm{K}_{2} \mathrm{O}$ & $\mathrm{TiO}_{2}$ & $\mathrm{P}_{2} \mathrm{O}_{5}$ & LOI & Total \\
\hline 221 & 2.53 & 3.13 & 1.31 & 0.28 & 0.09 & 5.24 & 99.82 \\
\hline 301 & 1.88 & 2.66 & 3.79 & 0.31 & 0.11 & 3.75 & 99.85 \\
\hline
\end{tabular}

$\mathrm{Na}_{2} \mathrm{O}+\mathrm{K}_{2} \mathrm{O}$

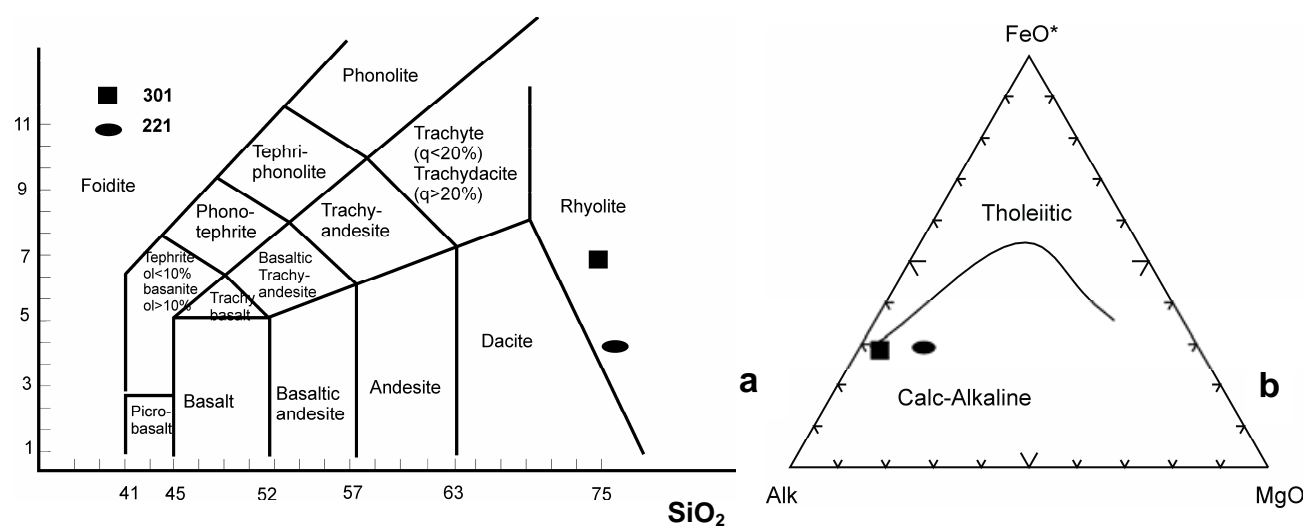

Fig. 4. Distribution of the ignimbrites in IAS (a) and AFM (b) diagrams.

Trace and rare earth element geochemistry outlined some important geochemical signatures. As a whole, the compatible trace elements, $\mathrm{V}, \mathrm{Co}, \mathrm{Cr}$ show low abundances, while highly incompatible elements (e.g. Rb) and light rare earth elements (LREE, e.g. La, Ce) present high contents (Tab. 5).

Some differences in the incompatible trace element $(\mathrm{Ba}, \mathrm{Rb}, \mathrm{Sr})$ contents have been noticed between the two ignimbrite occurrences, in contrast with the quite similar abundances of rare earth elements (REE) and high field strength elements (HFSE-Nb, Ta, Hf, $\mathrm{Zr}$ ).

Table 5

Trace and rare earth element analyses of ignimbrites

\begin{tabular}{|c|l|l|c|c|c|}
\hline \multirow{2}{*}{ Trace elements } & \multicolumn{2}{|c|}{ Sample } & \multirow{2}{*}{ Rare earth elements } & \multicolumn{2}{c|}{ Sample } \\
\cline { 2 - 3 } & $\mathbf{2 2 1}$ & $\mathbf{3 0 1}$ & $\mathbf{2 2 1}$ & $\mathbf{3 0 1}$ \\
\hline $\mathrm{V}$ & 19.2 & 25.6 & $\mathrm{La}$ & 35.7 & 31.9 \\
\hline $\mathrm{Cr}$ & 6.8 & 7.1 & $\mathrm{Ce}$ & 65.3 & 60.5 \\
\hline $\mathrm{Co}$ & 2.19 & 2.08 & $\mathrm{Pr}$ & 6.80 & 6.40 \\
\hline $\mathrm{Rb}$ & 39 & 90 & $\mathrm{Nd}$ & 23.7 & 21.7 \\
\hline $\mathrm{Sr}$ & 226 & 136 & $\mathrm{Sm}$ & 4.34 & 4.23 \\
\hline $\mathrm{Ba}$ & 434 & 815 & $\mathrm{Eu}$ & 1.15 & 0.91 \\
\hline $\mathrm{Cs}$ & 1.05 & 0.99 & $\mathrm{Gd}$ & 3.72 & 3.58 \\
\hline
\end{tabular}


ALEXANDRINA FÜLÖP, MARINEL KOVACS

\begin{tabular}{|c|c|c|c|c|c|}
\hline \multirow{2}{*}{ Trace elements } & \multicolumn{2}{|c|}{ Sample } & \multirow{2}{*}{ Rare earth elements } & \multicolumn{2}{c|}{ Sample } \\
\cline { 2 - 3 } & $\mathbf{2 2 1}$ & $\mathbf{3 0 1}$ & & $\mathbf{2 2 1}$ & $\mathbf{3 0 1}$ \\
\hline $\mathrm{Nb}$ & 11.9 & 13.1 & $\mathrm{~Tb}$ & 0.61 & 0.58 \\
\hline $\mathrm{Zr}$ & 189 & 204 & $\mathrm{Dy}$ & 3.55 & 3.44 \\
\hline $\mathrm{Ta}$ & 1.0 & 1.26 & $\mathrm{Ho}$ & 0.71 & 0.70 \\
\hline $\mathrm{Hf}$ & 4.48 & 5.05 & $\mathrm{Er}$ & 2.07 & 2.10 \\
\hline $\mathrm{Pb}$ & 15.5 & 20.04 & $\mathrm{Tm}$ & 0.32 & 0.35 \\
\hline $\mathrm{U}$ & 3.37 & 3.86 & $\mathrm{Yb}$ & 2.29 & 2.45 \\
\hline $\mathrm{Th}$ & 11.3 & 14.2 & $\mathrm{Lu}$ & 0.35 & 0.40 \\
\hline $\mathrm{Y}$ & 24.9 & 24.6 & & & \\
\hline
\end{tabular}

REE distribution in the chondrite-normalized diagram is shown in Fig. 5. Chondritic patterns with high light rare earth element (LREE) enrichments and Eu negative anomaly are similar with those of calc-alkaline, subduction-related magmas (Gill, 1981; Wilson, 1989). LREE enrichment correlated with high large ion lithofile elements - LILE/LREE ratios (e.g. Ba/La=12-25) - suggests the enrichment of the ignimbrites mantle source in these elements, most probably subducted slab contributions (fluids or silica melts, Hawkesworth et al., 1993; Green, 1997). The slight sigmoidal aspects of the REE variation curves in the chondrite-normalized diagram suggest the presence of fractional crystallization processes in the magmas responsible for ignimbrites. Plagioclase fractionation, as main process, is emphasized by Eu negative anomaly (plagioclase is the main juvenile crystal of the ignimbrites).

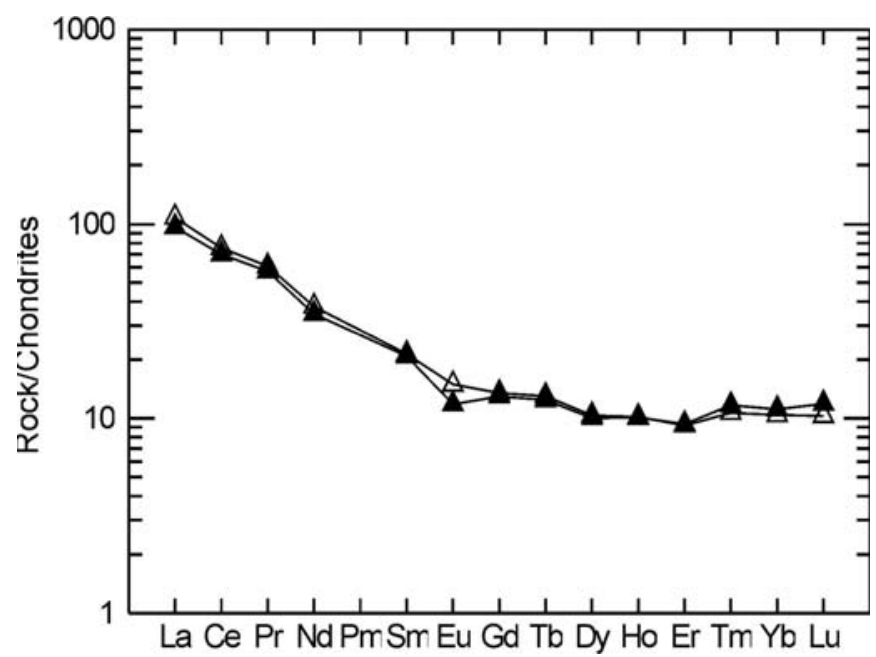

Fig. 5. REE distribution in chondrite-normalized diagram (normalizing values are from Nakamura, 1974).

NMORB-normalized incompatible trace element diagram (Fig. 6) shows interesting patterns with negative $\mathrm{Nb}, \mathrm{P}, \mathrm{Ti}$ troughs and positive spikes for $\mathrm{K}$ 
and $\mathrm{Pb}$ which are typical for subduction-related arc magmas (Wilson, 1989; Hawkesworth et al., 1993).

\section{Rock/NMORB}

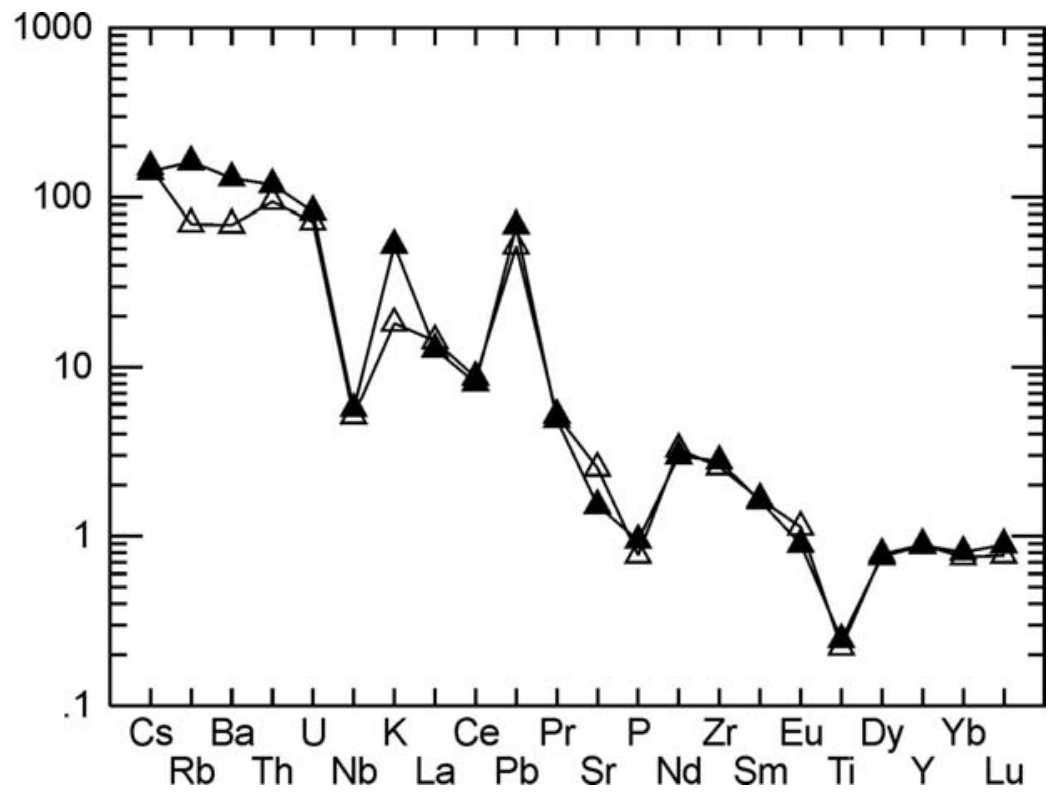

Fig. 6. N-MORB normalized incompatible trace element diagram of Badenian ignimbrites from Gutâi Mts. (normalizing values are from Sun \& McDonough, 1989).

LILE and LREE enrichments - comparative with a mantle source (average mantle values are around 1 in the NMORB-normalized diagrams, according to Sun \& McDonough, 1989) - are similar with those of intermediate arc-type volcanics from Gutâi Mts. (Kovacs, 2001, 2002).

The strong $\mathrm{Pb}$ positive anomaly suggests a mantle source enrichment, most probably by addition of subducted slab sediments. This process has been emphasized for Călimani-Gurghiu-Harghita (Mason et al., 1996) and Gutâi (Kovacs, 2001, 2002) volcanics.

Lead isotope analyses have been performed on two pumice clasts from syn-eruptive resedimented volcaniclastics (Toaca Valley, Ilba and Limpedea Valley, Băița), cogenetic with the ignimbrites (Tab. 6).

Determinations have been run in the geochemical laboratories of BRGM, Orléans, France. $\mathrm{Pb}$ isotope composition of the ignimbrites-related rocks suggests source enrichment by subducted-zone related sediments. In the ${ }^{207} \mathrm{~Pb} /{ }^{204} \mathrm{~Pb}-$ ${ }^{206} \mathrm{~Pb} /{ }^{204} \mathrm{~Pb}$ diagram (Fig. 7), the two pumice samples are plotted in the field of Călimani-Gurghiu-Harghita, Gutâi volcanics and actual oceanic sediments. 
Table 6

Lead isotopes of syn-eruptive resedimented pumice clasts

\begin{tabular}{|c|c|c|c|c|}
\hline Sample & Location & ${ }^{206} \mathbf{P b} /{ }^{204} \mathbf{P b}$ & ${ }^{207} \mathbf{P b} /{ }^{204} \mathbf{P b}$ & ${ }^{208} \mathbf{P b} /{ }^{204} \mathbf{P b}$ \\
\hline $\mathbf{5 8 1}$ & Limpedea V. (Băița) & 18.855 & 15.663 & 38.856 \\
\hline $\mathbf{1 9}$ & Toaca V. (Ilba) & 18.852 & 15.664 & 38.862 \\
\hline
\end{tabular}

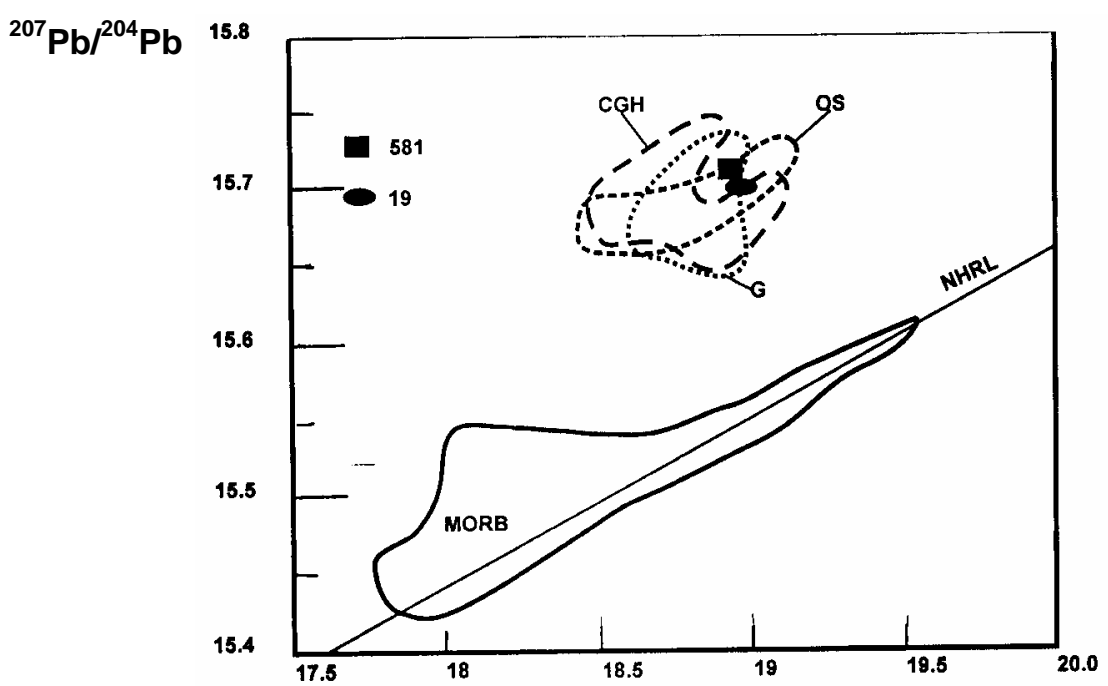

${ }^{206} \mathrm{~Pb} /{ }^{204} \mathrm{~Pb}$

Fig. 7. Lead isotope composition of ignimbrites: $M O R B=$ mid-ocean ridge basalts (Hawkesworth et al., 1994); CGH = Călimani-Gurghiu-Harghita (Mason et al., 1996); G = Gutâi Mts. (Kovacs, 2002);

OS = oceanic sediments (Hawkesworth et al., 1994); NHRL = Reference line of Hart (1984).

\section{CONCLUSIONS}

The ignimbrites represent the lowermost unit of the so called "Badenian Rhyodacitic Formation" and the earliest volcanics in Gutâi Mts. They have been defined as ignimbrites by evidence of welding.

According to their petrographic features, the ignimbrites are matrix-supported lapilli tuffs. They are composed of juvenile pyroclasts: fiamme, plagioclase, quartz and biotite as crystals and glass shards, in the fined-grained matrix. Secondary minerals obliterate most of the original features. Cognate pyroclasts are represented by porphyritic and aphyric non-vesicular glassy clasts and accidental lithic clasts are represented by fragments of the underlying Paleogene flysch and metamorphic basement, more or less reworked as fluvial debris. The andesitic clasts and pyroxene crystals could be interpreted as magmatic inclusions from a basic or intermediate magma batches, suggesting mingling/mixing processes, possibly in a zoned magma chamber. 
The reliable geochemical data - major and trace elements - have pointed out the rhyolitic character of the ignimbrites and the calc-alkaline character of their parental magmas. Trace and rare earth element geochemistry shows geochemical signatures resembling subduction zone-related volcanics (e.g. Gutâi Mts. and Călimani-Gurghiu-Harghita Mts.).

Strong LILE and LREE enrichments and the $\mathrm{Pb}$ isotope composition suggest mantle-source enrichment with subduction components (fluids and sediments).

The generation of the Badenian ignimbrites from Gutâi Mts. involves the evolution of the enriched mantle melts in crustal, possibly zoned magma chamber, by fractional crystallization, crustal assimilation and probably mingling/mixing processes. Magmagenesis could be related to the uprise of the enriched (by subduction components) astenospheric mantle below the Pannonian Basin. The rhyolitic volcanism has been triggered by extensional tectonics in the back-arc site.

Acknowledgements. We are indebted to: dr. Luminița Grancea, for the major and trace element analyses at University "Henri Poincaré", Nancy, dr. Eric Marcoux, for the lead isotope analyses at BRGM Orléans and dr. Alexandru Szakács, for running the microprobe analyses at Birkbeck Colledge, London. Many thanks to $\mathrm{dr}$. Ioan Denut for computer processing of the microprobe analyses.

\section{REFERENCES}

Borcoş, M., Lang, B., Peltz, S., Stan, N. 1972, Evolution of Neogen volcanism from the western part of Gutâi Mts. (Negreşti, Seini, Băița). St. Tehn. Econ., Ser.I, 6, 7-35, IGR Bucharest (in Romanian).

Csontos, L. 1995, Tertiary tectonic evolution of the Intra - Carpathian area: a review. Acta Vulcanologica, 7(2), p. 1-15.

Druitt, T.H. 1998, Pyroclastic density currents, in Gilbert J.S. \& Sparks R.S.J. (eds.): The physics of Explosive Volcanic Eruptions. Geological Society Special Publications no. 145 , London, p.145-182.

Fülöp, A. 2000, Morphology of pumice clasts and glass shards of the "Rhyodacitic Formation" in the Gutâi Mts., Eastern Carpathians; involved processes. Rom. J. Mineralogy, vol 80, p.63-68, Bucharest.

Fülöp, A. 2001, Sequential analysis of acide pyroclastics from the lower unit of the volcanic complex of Gutâi Mts. Paleovolcanic and Paleosedimentologic reconstructions. $\mathrm{Ph}$ D thesis, $163 \mathrm{p}$. University of Bucharest (in Romanian).

Fülöp, A. 2002, Facies analysis of volcaniclastic sequence built up above the $15.4 \mathrm{Ma}$ rhyolitic ignimbrites from Gutai Mts., Eastern Carpathians. Studia Universitatis Babeş-Bolyai, Geologia, Special issue, 1, p.199-206 Cluj-Napoca.

Fülöp A., Kovacs, M., Damian, F. 1991, Contributions to the petrographical study of the Rhyodacitic Badenian volcano-sedimentary formation from the Purcăreț and Puturoasa zones (Gutâi Mts.). The volcanic tuffs from Transylvania Basin, p. 245251, Cluj-Napoca. 
Green, T. H. 1997, Application of mineral/fluid/melt trace element partitioning data to models of arc magma genesis. State of the Arc'97. Geol. Society of Australia. Abs. No. 45, p. 30-33.

Gill, J. B. 1981, Orogenic andesites and plate tectonics. Springer Verlag, New York, 370 p.

Hart, S. R. 1984, A large-scale isotope anomaly in the Southern Hemisphere mantle. Nature, 309, p.753-757.

Hawkesworth, C. J., Gallagher, K., Hergt, J. M., McDermot, F. 1993, Mantle and slab contributions in arc magmas. Annual Review Earth Planetary Science, 21, p. 175-204.

Hawkesworth, C. J., Gallagher, K., Hergt, J. M., McDermot, F. 1994, Destructive plate margin magmatism: Geochemistry and melt generation. Lithos, 33, p. 169-188.

Kovacs, M. 2001, Subduction-related magmatism and associated metallogeny in Baia Mare region (Romania). In: Udubaşa, G. \& Kovacs, M. (eds.): Geodynamics and ore deposit evolution of the Alpine-Balkan-Carpathian-Dinaride Province, ABCDGEODE 2001 Workshop Field Guidebook. Rom. J. Mineral Deposits, vol.79, suppl.2, p.3-9.

Kovacs, M. 2002, Petrogenesis of the subduction magmatic rocks from centralsoutheastern area of Gutâi Mountains. Edit. Dacia; 202 p. (In Romanian)

Kovacs, M., Damian, F., Iştvan, E. 1989, Contributions to the petrographical study of the Badenian volcano-sedimentary formation from Igniş Mts. (Gutâi), with special emphasis on rocks from Lăpuşna-Galbena (Băița) and Fața Mare West (Ilba) ore deposits. St. cerc, geol., geofiz. GEOLOGIE, tom 34, p. 21-32, Bucharest (In Romanian)

Le Bas, M.J., Le Maître, R. W., Streckeisen, A., Zanetti, B. 1986, A Chemical Classification of Volcanic Rocks Based on the Total Alkali-Silica Diagram. Journal of Petrology, 27, p. 745-750.

Mason, P. R. D., Downes, H., Thirlwall, M. F., Seghedi, I., Szakács, A. D. P., Lowry, D., Mattey, D. 1996, Crustal contamination as a major petrogenetic process in the East Carpathian Neogene and Quaternary continental margin arc, Romania. Journal of Petrology, 37, p. 927-960.

Nakamura, N. 1974, Determination of REE, Ba, Fe, Mg, $\mathrm{Na}$ and $\mathrm{K}$ in carbonaceous and ordinary chondrites. Geochimica et Cosmochimica Acta, 38, p. 757-773.

R3/4dulescu, D. 1958, Petrographical study of the igneous formations from Seini-IlbaNistru (Baia Mare) region. An. Com. Geol., XXXI. (In Romanian)

Seghedi, I., Balintoni, I., Szakács, A. 1998, Interplay of tectonics and Neogene postcollisional magmatism in the Intracarpathian region. Lithos 45, p. 483-499

Sun, S. S. \& McDonough, W. F. 1989, Chemical and isotopic systematics of oceanic basalts: implication for mantle composition and processes: In: Saunders, A. D. and Norry, M. J. Magmatism in the ocean basins. Geological Society London Special publication, 42, p. 313-345.

Wilson, M. 1989, Igneous Petrogenesis. Wiley, London, 466 p. 